\title{
Urethral Foreign Body: An Uncommon Cause for Hematuria
}

\section{Corpo Estranho Uretral: Uma Causa Incomum de Hematúria}

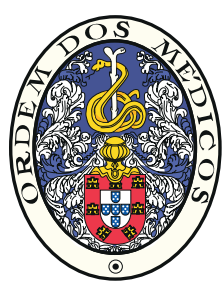

Tiago Ribeiro de OLIVEIRA $\rrbracket^{1}$, Pedro Simões de OLIVEIRA ${ }^{1}$, João Lemos ALMEIDA ${ }^{1}$

Acta Med Port 2017 Mar;30(3):251-251 - https://doi.org/10.20344/amp.7699

Keywords: Foreign Bodies; Hematuria; Self-Injurious Behavior; Urethra/injuries

Palavras-chave: Comportamento Autodestrutivo; Corpos Estranhos; Hematúria; Uretra/lesões
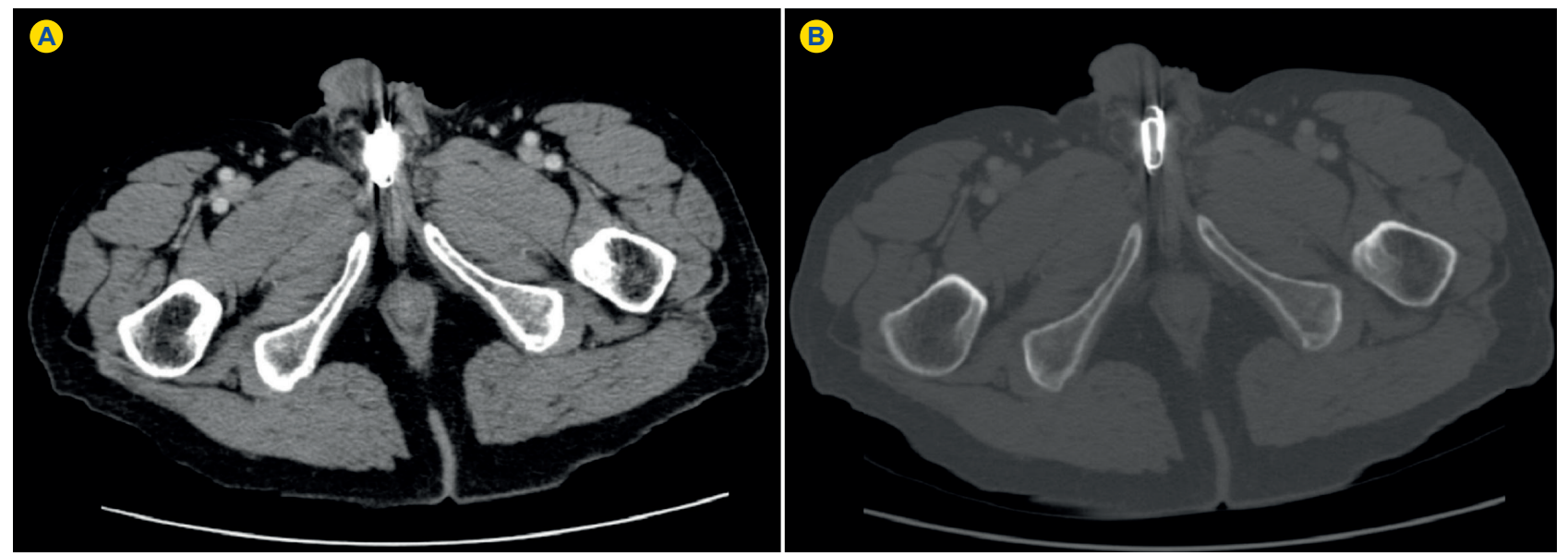

Figure 1 - Uro-CT with metallic-density foreign body in the proximal urethra (A: Abdomen window; B: Bone window)

A 59-years-old oligophrenic male, with past history of an intermediate risk prostate cancer treated with external beam radiotherapy and a solid kidney nodule under radiologic surveillance, presented with hematuria during the previous week.

Evaluation with ambulatory computed tomography urography (Uro-CT) confirmed a solid $25 \mathrm{~mm}$ mass in the right kidney, normal ureters and bladder, and a metallicdensity $20 \mathrm{~mm}$ foreign body in the proximal urethra (Fig. 1).

Flexible urethrocystoscopy under local anaesthesia identified two paper clips inside the proximal urethral lumen (Fig. 2), removed with endoscopic grasping forceps, without immediate complications. Subsequent urethrocystoscopy revealed superficial erosions on the proximal urethra, normal bladder mucosa and ureters emitting clear urine. No hematuria was detected thereafter.
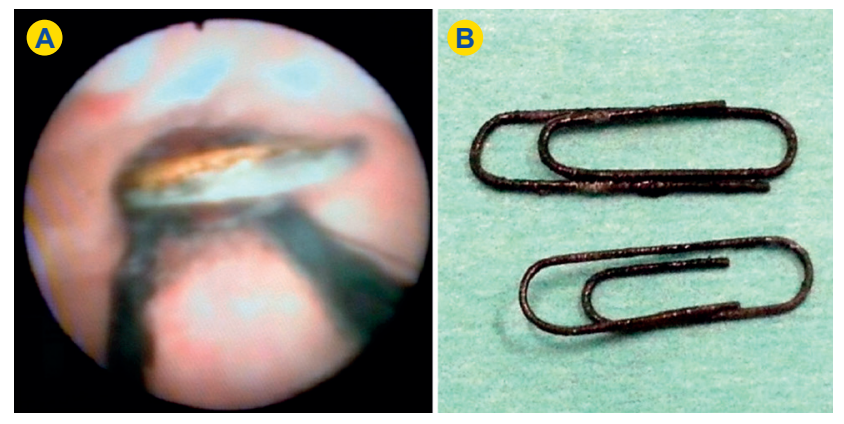

Figure 2 - Flexible urethrocystoscopy with two metallic paper clips inside the proximal urethra (A); Paper clips (B)

Despite the presence of several possible causes for hematuria, adequate diagnostic investigation revealed that a urethral foreign body was the causative factor and allowed successful endoscopic management. ${ }^{1-3}$

\section{REFERENCES}

1. Fath Elbab TK, Abdelhamid AM, Galal EM, Anwar AZ, Malek MA, Tawfiek ER. Management of intravesical self-inflicted sharp objects in children: 10-year single-center experience. J Pediatr Urol. 2016;12:97.e1-5.

2. Federici M, Guarna T, La Vecchia L, Pannunzio E, Farina F, Bellelli A. An unusual case of hematuria caused by a foreign body in the bladder: US and radiologic findings. J Ultrasound. 2008;11:168-70.

3. Aliabadi H, Cass AS, Gleich P, Johnson CF. Self-inflicted foreign bodies involving lower urinary tract and male genitals. Urology. 1985;26:12-6.

\footnotetext{
1. Department of Urology. Santa Maria University Hospital. Lisbon Medical Academic Center. Lisbon. Portugal.

$\triangle$ Autor correspondente: Tiago Ribeiro de Oliveira. tiagoribeirooliveira@sapo.pt

Recebido: 03 de abril de 2016 - Aceite: 25 de julho de 2016 | Copyright @ Ordem dos Médicos 2017
} 